\title{
An Integrated Survey of the Geochemical Study at the Blawan-Ijen Area, East Java
}

Riska Laksmita Sari1 ${ }^{*}$, Firman Sauqi Nur Sabila ${ }^{1}$, Haeruddin ${ }^{2}$, Eriska Eklezia Dwi Saputri ${ }^{1}$, Welayaturromadhona ${ }^{1}$, Hadziqul Abror ${ }^{1}$, Sartika Dwi Purwandari ${ }^{1}$, Agus Triono ${ }^{1}$ ${ }^{1}$ Department of Petroleum Engineering, Faculty of Engineering, University of Jember, Jl. Kalimantan No. 47, Jember, East Java, Indonesia - 68121

2Department of Mining Engineering, Faculty of Engineering, University of Jember, Jl. Kalimantan No. 47, Jember, East Java, Indonesia - 68121*

Corresponding Author: riska.laksmita@unej.ac.id

\begin{tabular}{l}
\hline Article History: \\
\hline Received: July 12, 2020 \\
Receive in Revised Form: December 10, \\
2020 \\
Accepted: December 22, 2020 \\
\hline
\end{tabular}

\section{Keywords:}

Geochemical, bicarbonate, chloride, sulphate, upflow.

\begin{abstract}
Geothermal energy is a renewable alternative energy source. One of the analyses used to determine the characteristics of a geothermal field is water geochemical analysis. The target of this research is the Blawan-Ijen geothermal prospect area, Bondowoso. The geochemical analysis was carried out using AAS, Spectrophotometer and acidbase titration. This survey shows the characteristics of the geothermal system and geothermal fluid in the Blawan area, Ijen. From the chemical analysis of hot water, we found that the types of geothermal water fluids in the Blawan Ijen area vary. In samples BL1, BL2 and BL5 included in the type of Sulphate Water with the dominant elemental Sulphate (SO4) content is also known as Sulfuric Acid Water (Acid-Sulphate Water). Then for the BL4 sample included in the type of chloride water. This type of water is a type of geothermal fluid found in most areas with high-temperature systems. Areas with large-scale hot springs flowing with high $\mathrm{Cl}$ concentrations originate from deep reservoirs and indicate permeable zones in those areas. However, this area may not be located above the main upflow zone. There are several other possibilities, such as topographic influences, which can significantly impact hydrological control. The presence of chlorine gas can also identify high zones' permeable areas (e.g., faults, breccia eruptions or conduit). In contrast, BL3 samples are included in the Bicarbonate Water-type. The element HCO3 (bicarbonate) is the most dominant element (main anion) and contains $\mathrm{CO} 2$ gas from the chemical analysis results. $\mathrm{HCO} 3$ water is generally formed in marginal and near-surface areas in systems dominated by volcanic rocks, where $\mathrm{CO} 2$ gas and condensed water vapour into groundwater. The vapour condensation can either heat the groundwater or be heated by steam (steam heated) to form an HCO3 solution.
\end{abstract}

\section{INTRODUCTION}

Geothermal is an environmentally friendly energy source because it uses repeated fluid injection under the earth's surface. Reinjection of geothermal fluid after the fluid is used for electricity generation and the recharge (seepage) of surface water, making geothermal energy sustainable (Nasional, 1998). Emissions from geothermal power plants are very low when compared to oil and coal. Because of its low emissions, geothermal energy has the criteria according to the Kyoto Protocol Clean Development Mechanism (CDM) product. This mechanism stipulates that developed countries must reduce greenhouse gas (GHG) emissions by $5.2 \%$ below the 1990 level. It should be done by purchasing clean energy from developing countries whose projects were built above 2000 (Kementrian ESDM, 2005). Clean energy includes geothermal. The development of geothermal energy can be one solution to increase Indonesia's energy reserves aside from fossil fuels. According to existing research, Indonesia is known as the country with enormous geothermal energy potential globally, with around $40 \%$ of its geothermal potential. However, in its use, Indonesia is still lagging behind other countries such as New Zealand and the Philippines (Badan Standarisasi Nasional, 
1999). Indonesia has about 265 existing geothermal areas with 138 locations (52.07\%) of those existing geothermal areas still at the initial preliminary stage. Simultaneously, 24 other locations (9.05\%) are still at the introduction investigation stage to the resource class hypothetical potential (Maryanto et al., 2017).

The Ministry of Research and Technology of the Republic of Indonesia (Kemenristekdikti), as one of the state institutions responsible for technology development in Indonesia, has established a roadmap for research, development and application of science and technology in the field of new and renewable energy sources to support the security of energy availability in the year 2025. In this roadmap, geothermal/geothermal energy is one of the focuses. In line with the roadmap of the Ministry of Research and Technology of the Republic of Indonesia, UNEJ (Universitas Jember) is building its capacity in the field of geothermal science and technology development. The ability of UNEJ in the geothermal field is directed primarily to process geothermal potential in East Java. East Java has a geothermal potential of $774 \mathrm{MWe}$, spread in 11 locations, one of which is in Blawan-Ijen, Bondowoso Regency. The Ijen caldera was formed more than 50,000 years ago due to the Ijen stratovolcano collapse (van Hinsberg et al., 2010). The BlawanIjen volcano complex also has a high potential for agriculture for primary commodities such as coffee, timber, and fruits. Furthermore, lush natural conditions in the caldera of old Ijen are home to residents with the Sempol district's establishment in Bondowoso (Konstantinou et al., 2013).

These stages are mandatory, considering the enormous geothermal investment costs. Stages Preliminary and exploration surveys are the initial stages of geothermal reservoirs' characterisation, which are very important. These stages include the study of geology, geophysics, and geochemistry. If at this stage carried out in detail and correctly, then the investment risk can be minimised (Hutapea F, 2010).

This research's targets are geochemical studies in the Blawan-Ijen geothermal area, a continuation of previous studies (characterisation of rock parameters and remote sensing analysis). This knowledge is essential for potential investors for geothermal developers to reduce their investment risk. Blawan-Ijen was chosen because it is close to the UNEJ campus, which in the future could be developed as a natural laboratory for the earth, not only in the geothermal field. Several field measurements have been carried out by the Center for Geological Resources (PSDG), the National Geological Agency. This study's results can be expected to improve the quality of potential interpretations that have been done before. Thus, investors will be more confident to participate in the Blawan-Ijen WKP auction because trust in the data and models is getting higher. This condition means that the risk of exploration failure can be reduced. Indirectly, these results are essential to be fostered for collaboration with geothermal development investors, including governments that regulate through regulations, in the form of both laws and government regulations.

This research aims to characterise the geological reservoir of Blawan, Ijen, with geochemical analysis.

\section{MATERIAL AND METHOD}

\section{Material}

The study was conducted in Mount Ijen and its surroundings (Figure 1). The presence of geothermal potential is characterised by hot springs scattered in the north of the area (Zaennudin et al., 2012). The materials used in this study are secondary data, namely the regional geological map of Mount Ijen and the map of geothermal manifestations on Mount Ijen, East Java.

The tools used in this study include:

a. Roll meter, room blade, permanent marker, a geological hammer, plastic, field book, geological compass, and $\mathrm{pH}$ meter.

b. GPS (Global Positioning System) The use of GPS to determine the coordinates of sampling points in the field.

\section{Method}

Research Stages in this study include:

a. Literature Study

This study begins with the literature collection from previous research that discusses Mount Ijen, East Java's geological and geographic conditions. 
An Integrated Survey of The Geochemical Study at The Blawan-Ijen Area, East Java (R L Sari, F S N Sabila, Haeruddin, E E D Saputri, Welayaturromadhona, H Abror, S D Purwandari, A Triono)

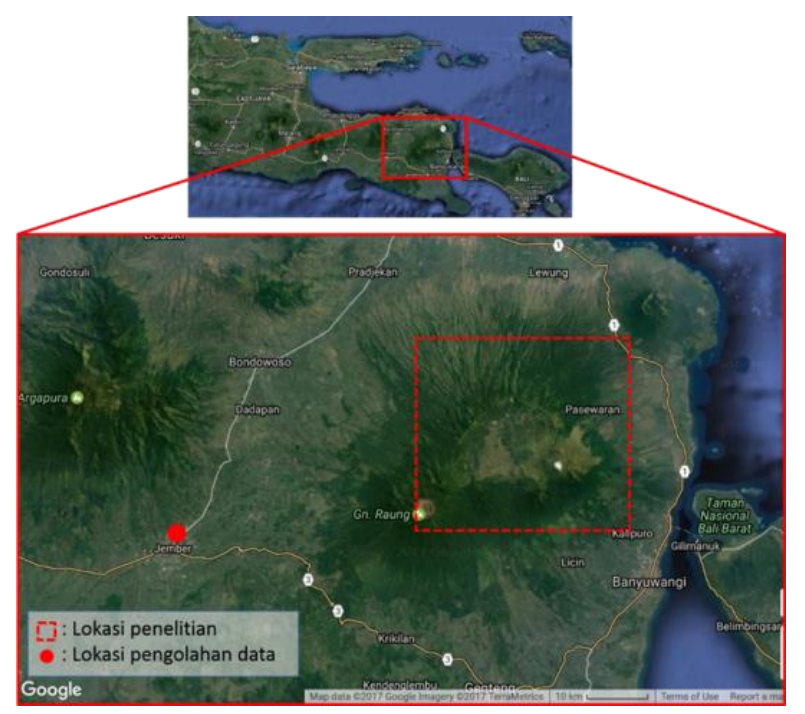

Figure 1. Location of the study area at Blawan-Ijen area, East Java

b. Collection of field samples

Sample collection is carried out in two stages, namely collecting rock samples, and collecting hot water samples. Collection of rock samples using random map trajectories. Determination of coordinates using Global Positioning System (GPS). The collection of hot water samples is done by taking hot water samples at several different points. Hot water geochemical survey refers to the GNS Science New Zealand Standard

\section{c. Data Processing}

Data processing begins with the analysis of hot water content in concentrations of cations and primary element anions. We use F-AAS tools and spectrophotometers. Furthermore, geochemical data is processed and plotted into ternary diagrams ( $\left.\mathrm{Cl}-\mathrm{SO}_{4}-\mathrm{HCO}_{3}, \mathrm{Cl}-\mathrm{Li}-\mathrm{B}, \mathrm{Na}-\mathrm{K}-\mathrm{Mg}\right)$. Furthermore, the process of calculating subsurface temperature estimation is carried out using the geothermometer method.

\section{d. Interpretation of Data}

After data processing is complete, interpretation is based on the leading element's anion cation content. Based on these results, an interpretation in geological and geochemical geothermal studies in Blawan, Ijen. The geothermal reservoir is where hydrothermal fluids heated by the heat source, which here means hot rock.

\section{e. Data Validation}

The interpretation results are then validated with primary and secondary data (geological maps, geological structure distribution and geothermal manifestations). It aims to get an accurate interpretation and following field conditions in the Blawan-Ijen area.

\section{RESULT AND DISCUSSION Measurement of Field Data}

Measurement and data collection in the field were carried out in three locations: Blawan hot springs, Wurung Crater, and Kalipahit River, as shown in Figure 2. The first location, the Blawan-Ijen hot spring location, is taken with three points. At this location, hot springs were found with $50.9^{\circ} \mathrm{C}$ and $\mathrm{pH}$ of 5.8 , while air temperatures were $26.6{ }^{\circ} \mathrm{C}$. In the second point, hot springs were found with $\mathrm{T} 44.4{ }^{\circ} \mathrm{C}$ and $\mathrm{pH} 6.6$, while the air temperature was $26.1^{\circ} \mathrm{C}$, there was dense vegetation surrounded by large trees. The third point is the limestone cave on the riverbank and closes to the Blawan waterfall.

In the Wurung Crater, the second location obtained a surface temperature of $22.6{ }^{\circ} \mathrm{C}$. The pick-up location is at five points. The sampling points are BL $1, \mathrm{BL} 2, \mathrm{BL} 3, \mathrm{BL} 4$, and BL 5, respectively denoted by STA 04 , STA 05, STA 06, STA 07, and STA 08 in Figure 2. The vegetation is dominated by grass. In the Kalipahit river, the third location obtained water with a very acidic $\mathrm{pH}(<0.01)$ with a temperature of $22.5{ }^{\circ} \mathrm{C}$. At the same time, the existing rock is volcanic breccia. This river is a stream from the Ijen crater, which crosses the Blawan region. It mixes with neutral pH water in the Blawan waterfall (Suciningtyas et al., 2013).

\section{Water Geochemical Test}


The test aims to know the type of hot water fluid and find out the reservoir temperature using the element geothermometer calculation.

The test uses various spectrophotometer, AAS (Atomic Absorption Spectroscopy) and acid-base titration. $\mathrm{Na}, \mathrm{Ca}, \mathrm{K}$, and $\mathrm{Mg}$ contents were tested using AAS. The $\mathrm{SO}_{4}, \mathrm{Cl}$ and $\mathrm{B}$ contents were tested using a spectrophotometer. As for $\mathrm{HCO}_{3}$, it is carried out using acid-base titration. Water samples were tested on five samples stabilised from 5 points. The results of sample testing with the AAS method and the spectrophotometer are shown in Table 1. While testing for $\mathrm{HCO}^{3}$ using the acid-base titration method is being carried out in the lab. MIPA analytical chemistry.

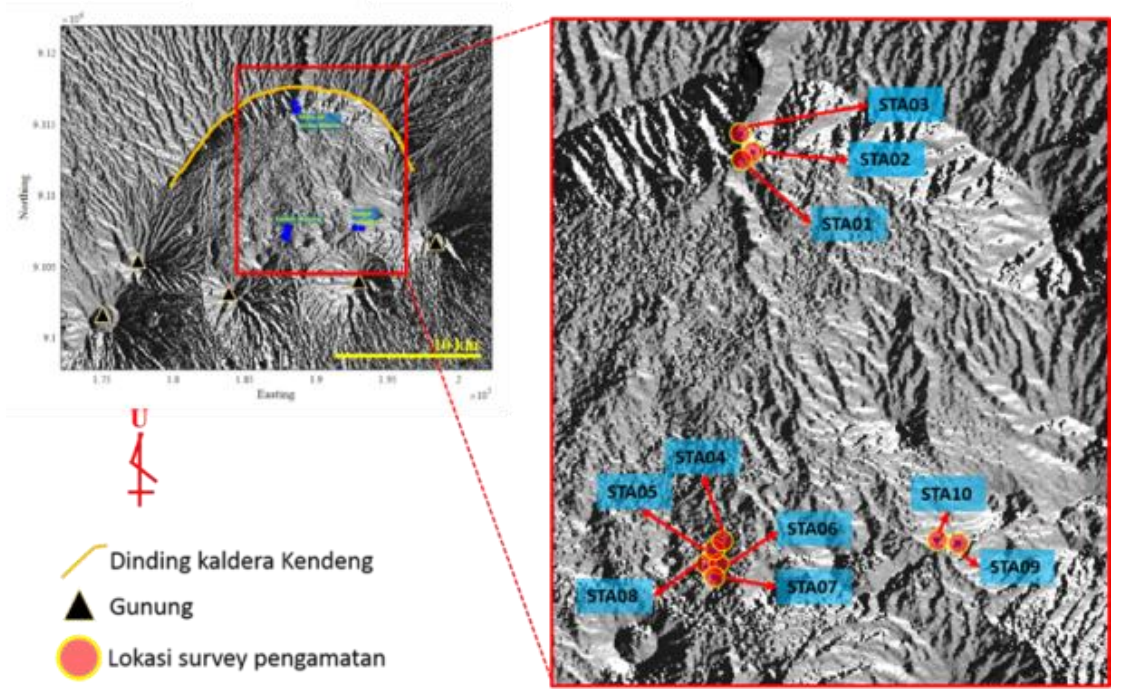

Figure 2. Location of data retrieval in the field

To determine the levels of $\mathrm{HCO}^{3-}$ in hot spring samples, the acid-base titration method was used. The sample is put into the beaker as much as $100 \mathrm{ml}$. The $\mathrm{pH}$ meter is put into the beaker, then titrated with $\mathrm{H}_{2} \mathrm{SO}_{4}$ solution up to $\mathrm{pH} 4.5$. The volume of $\mathrm{H}_{2} \mathrm{SO}_{4}$ used in the titration process is recorded. The volume of $\mathrm{H}_{2} \mathrm{SO}_{4}$ used in the titration process is recorded. The $\mathrm{HCO}_{3}$ level is calculated by equation (1).

$$
\mathrm{HCO}_{3}^{-}=\frac{A \cdot N \cdot 50000}{V}
$$

A is the volume of the $\mathrm{H} 2 \mathrm{SO} 4$ solution used in the titration process. $\mathrm{N}$ is the normality of $\mathrm{H}_{2} \mathrm{SO}_{4}$, and $\mathrm{V}$ is the sample volume.

Table 1. Geochemical analysis

\begin{tabular}{lllll}
\hline Sample & Ion & Unit & Value & Analysis Method \\
\hline BL1 & Sodium (Na) & ppm & 104 & F-AAS \\
& Calcium (Ca) & ppm & 72 & F-AAS \\
& Kalium (K) & ppm & 32 & F-AAS \\
& Magnesium (Mg) & ppm & 107 & F-AAS \\
& Sulphate (SO $\left.{ }_{4}\right)$ & ppm & 297 & Spectrophotometer \\
& Chloride (Cl) & ppm & 138 & Spectrophotometer \\
& Boron (B) & ppm & 4 & Spectrophotometer \\
BL2 & HCO ${ }_{3}$ & ppm & 737 & Acid-Base Titration \\
& Sodium (Na) & ppm & 47 & F-AAS \\
& Calcium (Ca) & ppm & 14 & F-AAS \\
& Kalium (K) & ppm & 32 & F-AAS \\
& Magnesium (Mg) & ppm & 42 & F-AAS \\
& Sulphate $\left(\mathrm{SO}_{4}\right)$ & ppm & 47 & Spectrophotometer \\
\hline
\end{tabular}


An Integrated Survey of The Geochemical Study at The Blawan-Ijen Area, East Java (R L Sari, F S N Sabila, Haeruddin, E E D Saputri, Welayaturromadhona, H Abror, S D Purwandari, A Triono)

\begin{tabular}{|c|c|c|c|c|}
\hline & Chloride (Cl) & ppm & 38 & Spectrophotometer \\
\hline & Boron (B) & ppm & 3 & Spectrophotometer \\
\hline & $\mathrm{HCO}_{3}$ & ppm & 421 & Acid-Base Titration \\
\hline \multirow[t]{8}{*}{ BL3 } & Sodium (Na) & ppm & 94 & F-AAS \\
\hline & Calcium (Ca) & ppm & 63 & F-AAS \\
\hline & Kalium (K) & ppm & 34 & F-AAS \\
\hline & Magnesium (Mg) & ppm & 63 & F-AAS \\
\hline & Sulphate $\left(\mathrm{SO}_{4}\right)$ & ppm & 165 & Spectrophotometer \\
\hline & Chloride (Cl) & ppm & 80 & Spectrophotometer \\
\hline & Boron (B) & ppm & 4 & Spectrophotometer \\
\hline & $\mathrm{HCO}_{3}$ & ppm & 620 & Acid-Base Titration \\
\hline \multirow[t]{8}{*}{ BL4 } & Sodium (Na) & ppm & 83 & F-AAS \\
\hline & Calcium (Ca) & ppm & 71 & F-AAS \\
\hline & Kalium (K) & ppm & 28 & F-AAS \\
\hline & Magnesium (Mg) & ppm & 57 & F-AAS \\
\hline & Sulphate $\left(\mathrm{SO}_{4}\right)$ & ppm & 147 & Spectrophotometer \\
\hline & Chloride (Cl) & ppm & 76 & Spectrophotometer \\
\hline & Boron (B) & ppm & 4 & Spectrophotometer \\
\hline & $\mathrm{HCO}_{3}$ & ppm & 532 & Acid-Base Titration \\
\hline \multirow[t]{8}{*}{ BL5 } & Sodium (Na) & ppm & 527 & F-AAS \\
\hline & Calcium (Ca) & ppm & 13 & F-AAS \\
\hline & Kalium (K) & ppm & 735 & F-AAS \\
\hline & Magnesium (Mg) & ppm & 382 & F-AAS \\
\hline & Sulphate $\left(\mathrm{SO}_{4}\right)$ & ppm & 40595 & Spectrophotometer \\
\hline & Chloride (Cl) & ppm & 19430 & Spectrophotometer \\
\hline & Boron (B) & ppm & 33 & Spectrophotometer \\
\hline & $\mathrm{HCO}_{3}$ & ppm & - & Acid-Base Titration \\
\hline
\end{tabular}

\section{Type of Hot Water}

Chemical data needed in determining the type of reservoir fluid is the relative content of chloride $(\mathrm{Cl})$, bicarbonate $\left(\mathrm{HCO}_{3}\right)$ and Sulphate $\left(\mathrm{SO}_{4}\right)$. Data processing is done by calculating the percentage of elements of chloride $(\mathrm{Cl})$, bicarbonate $\left(\mathrm{HCO}_{3}\right)$ and Sulphate $\left(\mathrm{SO}_{4}\right)$. Then the data is plotted in the Giggenbach triangle diagram (Figure 3). This diagram is used to indicate the characteristic type of geothermal water and subsurface geothermal conditions. The dissolved ions in the surface ascending thermal fluids originate (Sukhyar et al., 2014). 


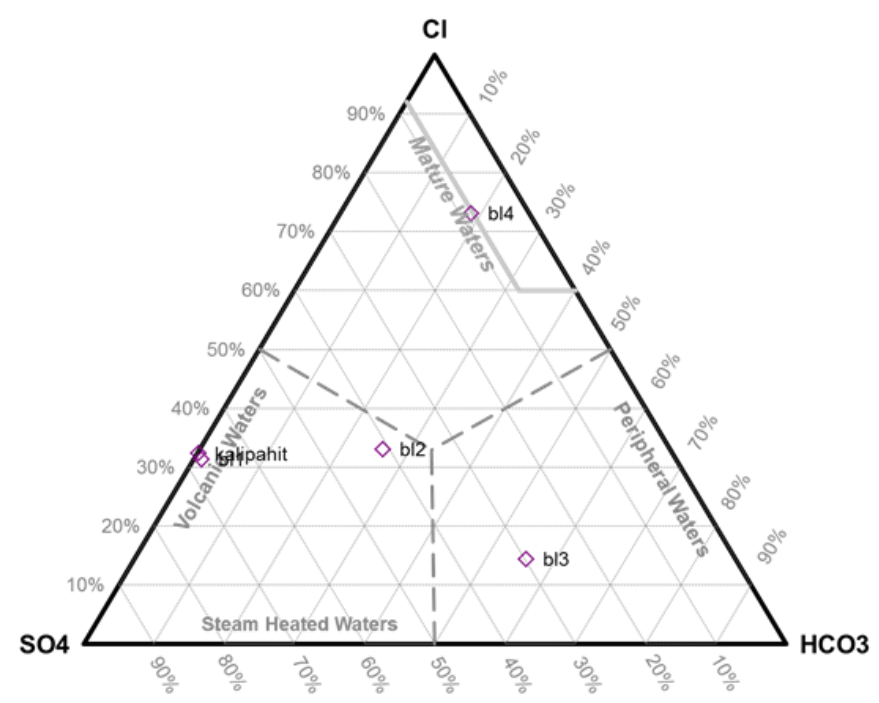

Figure 3. Ternary Diagram of $\mathrm{Cl}-\mathrm{SO}_{4}-\mathrm{HCO}_{3}$ elemental content of hot water in Blawan, Ijen

The types of geothermal water fluids found in the Blawan Ijen area vary from the chemical analysis results. In the BL 1 and BL5 samples included in Sulphate Water's type with the dominant content of Sulphate $\left(\mathrm{SO}_{4}\right)$. This type of geothermal water, also known as Sulfuric Acid, is a fluid that forms at shallow depths and is formed due to the condensation of geothermal gas goes near the surface. Geothermal gas, with its gas and volatile content, is practically soluble in fluid content, which is located in a deep zone but is separated from chloride water. Sulphate water is usually found at the boundary and not far from the main upflow area. When viewed from the topography, the exact location is far above the water table and around the boiling zone. However, most are often found near the surface (at depths $<100 \mathrm{~m}$ ). Sulphate water can flow through faults to the geothermal system. Sulphate water is heated at this location, then takes part in rock alterations and mixes with chlorine water.

Then for the BL 4 sample included in the type of chloride water. This type of water is a type of geothermal fluid found in most areas with high-temperature systems. Areas with large-scale hot springs flowing with high $\mathrm{Cl}$ concentrations originate from deep reservoirs and indicate permeable zones in those areas. However, this area may not be located above the main upflow zone because there are several other possibilities, such as topographic influences, which can significantly impact hydrological control. The eyes of chloride can also identify high zones' permeable areas (e.g., faults, breccia eruptions or conduit).

Meanwhile, BL3 samples are included in the Bicarbonate Water-type. The element HCO3 (bicarbonate) is the most dominant element (primary anion) and contains $\mathrm{CO} 2$ gas from the chemical analysis results. $\mathrm{HCO} 3$ water is generally formed in marginal and near-surface areas in systems dominated by volcanic rocks, where $\mathrm{CO}_{2}$ gas and condensed water vapour into groundwater. The vapour condensation can either heat the groundwater or be heated by steam (steam heated) to form an $\mathrm{HCO}_{3}$ solution. $\mathrm{HCO}_{3}$ water is formed below the groundwater level. It is generally weak acidic, but with dissolved $\mathrm{CO}_{2}$, this water's degree of acidity can increase to neutral or slightly alkaline (van Hinsberg et al., 2010). The alterations found are generally argillic (kaolinite, montmorillonite) and mordenite. The high levels of $\mathrm{HCO}_{3}$ found in Blawan springs probably resulted from the mixing of surface groundwater with $\mathrm{CO}_{2}$ rich steam, which boiled off the hydrothermal system (Delmelle et al., 2000).

\section{Na-K - Mg Geoindicator}

The triangular diagram of Na / 1000 - K / 100 shown by Giggenbach (1988) is used to estimate reservoir temperatures and calculate the water that reaches equilibrium in lithology. The plotting is done on the $\mathrm{Na}$ / 1000 - K / 100 - Mg1 / 2 triangle diagram (Figure 4) for each hot spring sample from the data and the percentage calculation of the three elements' contents. 
An Integrated Survey of The Geochemical Study at The Blawan-Ijen Area, East Java (R L Sari, F S N Sabila, Haeruddin, E E D Saputri, Welayaturromadhona, H Abror, S D Purwandari, A Triono)

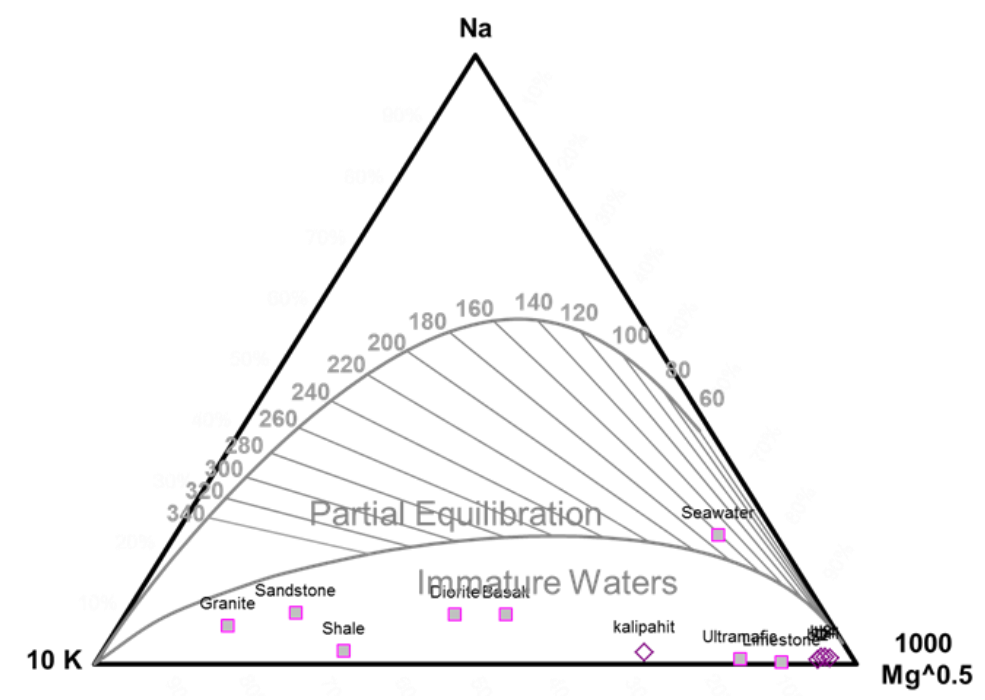

Figure 4. Ternary Diagram of Na, K, Mg elements in hot water in Blawan, Ijen

Based on the calculation of the relative content of $\mathrm{Na} / 1000-\mathrm{K} / 100-\mathrm{Mg}^{1 / 2}$, the value of the Na hot springs triangle lies in showing that the manifestation temperature that appears on the surface tends to be low. It also influenced by the interaction between hydrothermal fluid and elements in rocks through which silica passes. The condition of immature water is that the reservoir rock is located at a high temperature and pressure condition. Before it reaches the surface, it has also been diluted by surface water (meteoric water).

\section{Na-K-Ca Geothermometer}

A good temperature range for use with $\mathrm{Na}-\mathrm{K}$-Ca geothermometer is $120^{\circ} \mathrm{C}$ to $200^{\circ} \mathrm{C}$, and the rest is not very good. This geothermometer is useful when applied to water that has a high Ca concentration. For calculating the temperature of $\mathrm{Na}-\mathrm{K}-\mathrm{Ca}$, the following equation is used:

$$
T^{\circ} \mathrm{C}=\frac{1647}{\log (N a / K)+\beta(\log \sqrt{C a / N a}+2,06)+2,47}-273,15
$$

Table 2. Temperature Na-K-Ca $(\beta=4 / 3)$

\begin{tabular}{lll}
\hline No & Sample & $\mathrm{T}^{\circ} \mathrm{C}$ \\
\hline 1 & BL1 & 98.84 \\
2 & BL2 & 185.08 \\
3 & BL3 & 106.47 \\
4 & BL4 & 92.03 \\
5 & BL 5 (Kalipahit) & 621.80 \\
\hline
\end{tabular}

Based on Na-K-Ca temperature calculation using $\beta=4 / 3$, the temperature values obtained for samples BL2, $\mathrm{BL} 3$, and BL4 $>100^{\circ} \mathrm{C}$ while BL4 samples temperature $<100{ }^{\circ} \mathrm{C}$ and BL5 (Kalipahit) values are very high, the results not acceptable (See Table 2). For this reason, a recalculation is performed using $\beta=1 / 3$ and the results obtained in Table 3.

Based on the calculation results in Table 3, all samples' temperature is obtained, ranging from $63-166^{\circ} \mathrm{C}$. From these results, the Na-K-Ca geothermometer estimation is not very good because it is good to be used in the temperature range of $120-200{ }^{\circ} \mathrm{C}$. The rest is not too good despite the value of water samples analysis with high Ca concentrations. 
Table 3. Temperature Na-K-Ca $(\beta=1 / 3)$

\begin{tabular}{lll}
\hline No & Sample & ${ }^{\mathrm{T}}{ }^{\circ} \mathrm{C}$ \\
\hline 1 & BL1 & 63.78 \\
2 & BL2 & 99.37 \\
3 & BL3 & 69.02 \\
4 & BL4 & 64.42 \\
5 & BL 5 (Kalipahit) & 166.14 \\
\hline
\end{tabular}

\section{Na-K Geothermometer}

$\mathrm{Na}-\mathrm{K}$ geothermometer can be applied to chloride water reservoirs with $\mathrm{T}>180^{\circ} \mathrm{C}$. However, this geothermometer is not good when applied to $\mathrm{T}<100^{\circ} \mathrm{C}$ (Simmons, 1998). For determining the subsurface temperature using a geothermometer with $\mathrm{Na}-\mathrm{K}$ content, the following equation is used:

$$
\begin{aligned}
& N a-K \rightleftarrows(\text { Fourier }) T^{\circ} \mathrm{C}=\frac{1217}{(\log N a / K)+1,483}-273 T>180^{\circ} \mathrm{C} \\
& N a-K \rightleftarrows(\text { Giggenbach }) T^{\circ} \mathrm{C}=\frac{1390}{(\log N a / K)+1,75}-273 T>120^{\circ} \mathrm{C}
\end{aligned}
$$

Table 4. Temperature Na-K (Fournier)

\begin{tabular}{lll}
\hline No & Sample & $\mathrm{T}^{\circ} \mathrm{C}$ \\
\hline 1 & BL1 & 337,06 \\
2 & BL2 & 464,60 \\
3 & BL3 & 359,32 \\
4 & BL4 & 349,53 \\
5 & BL 5 (Kalipahit) & 636,21 \\
\hline
\end{tabular}

Table 5. Temperature Na-K (Giggenbach)

\begin{tabular}{lll}
\hline No & Sample & $\mathrm{T}^{\circ} \mathrm{C}$ \\
\hline 1 & BL1 & 265,05 \\
2 & BL2 & 464,60 \\
3 & BL3 & 359,32 \\
4 & BL4 & 349,53 \\
5 & BL 5 & 636,21 \\
\hline
\end{tabular}

Based on temperature calculations using two equations, high-temperature results are obtained, namely $337-636^{\circ} \mathrm{C}$ for the Fournier Equation (Table 4) and $265-636^{\circ} \mathrm{C}$ for the Giggenbach Equation (Table 5). This geothermometer is not suitable if the water contains high Ca. From the analysis of water samples with high Ca content, this geothermometer cannot estimate reservoir temperatures. Alternative geothermometers, such as the Na-K, are not suitable for the Blawan hot spring conditions due to their high-Ca content and log $((\mathrm{Ca} / \mathrm{Na})+2.06)$ are positive. The $\mathrm{Na}-\mathrm{K}$ geothermometer requires a low $\mathrm{Ca}$ content and a negative value for $\log \left(\left(\mathrm{Ca}^{0.5} / \mathrm{Na}\right)+2.06\right)$. Additionally, the $\mathrm{Na}-\mathrm{K}$ geothermometer is applicable for reservoirs with temperature ranges from 180 to $350{ }^{\circ} \mathrm{C}$ (Ellis, 1979). 
An Integrated Survey of The Geochemical Study at The Blawan-Ijen Area, East Java

(R L Sari, F S N Sabila, Haeruddin, E E D Saputri, Welayaturromadhona, H Abror, S D Purwandari, A Triono)

\section{K-Mg Geothermometer}

This geothermometer is applied to situations where dissolved $\mathrm{Na}$ and Ca have not been balanced between liquid and rock. To determine subsurface temperature using a geothermometer with Na-K content, we can use equation (5):

$$
T^{\circ} \mathrm{C}=\frac{4410}{14.0+\log \left(K^{2} / M g\right)}-273
$$

Table 6. Temperature K-Mg (Giggenbach)

\begin{tabular}{lll}
\hline No & Sample & ${ }^{\circ}{ }^{\circ} \mathrm{C}$ \\
\hline 1 & BL1 & 66,89 \\
2 & BL2 & 77,88 \\
3 & BL3 & 74,47 \\
4 & BL4 & 71,07 \\
5 & BL 5 (Kalipahit) & 135,20 \\
\hline
\end{tabular}

Based on the calculation results in Table 6, the temperature is obtained using the K-Mg temperature estimation (Giggenbach, 1991). All hot springs in the range between $66-135^{\circ} \mathrm{C}$. For geothermometers, this is best used when re-equilibrium takes place quickly at low temperatures. The K-Mg geothermometer is generally used in conjunction with the $\mathrm{Na}-\mathrm{K}$ geothermometer, using a $\mathrm{Na}-\mathrm{K}-\mathrm{Mg}$ triangle diagram.

\section{CONCLUSION}

From the results of the chemical analysis, it is known that the types of geothermal water fluids found in the Blawan Ijen area vary. In samples BL1, BL2 and Kalipahit included in Sulphate Water with the dominant elemental Sulphate $\left(\mathrm{SO}_{4}\right)$ content. This type of geothermal water is also known as Sulfuric Acid Water (AcidSulphate Water). Then for the BL 4 sample included in the type of chloride water. This type of water is a type of geothermal fluid found in most areas with high-temperature systems. Areas with large-scale hot springs flowing with high $\mathrm{Cl}$ concentrations originate from deep reservoirs and indicate permeable zones in those areas. However, this area may not be located above the main upflow zone because there are several other possibilities, such as topographic influences, which can significantly impact hydrological control. The eyes of chloride can also identify high zones' permeable areas (e.g., faults, breccia eruptions or conduit). In contrast, BL3 samples are included in the Bicarbonate Water-type. The element HCO3 (bicarbonate) is the most dominant element (main anion) and contains $\mathrm{CO} 2$ gas from the results of chemical analysis. $\mathrm{HCO} 3$ water is generally formed in marginal and near-surface areas in systems dominated by volcanic rocks, where $\mathrm{CO}_{2}$ gas and condensed water vapour into groundwater. The vapour condensation can either heat the groundwater or be heated by steam (steam heated) to form an $\mathrm{HCO}_{3}$ solution.

\section{Acknowledgements}

The author thanks the LP2M University of Jember for funding support so that this research can be carried out well.

\section{REFERENCES}

Badan Standarisasi Nasional. (1999). Metoda Estimasi Potensi Energi Panasbumi.

Delmelle, P., Bernard, A., Kusakabe, M., Fischer, T. P., \& Takano, B. (2000). Geochemistry of the magmatichydrothermal system of Kawah Ijen volcano, East Java, Indonesia. Journal of Volcanology and Geothermal Research, 97(1-4), 31-53. https://doi.org/10.1016/S0377-0273(99)00158-4

Ellis, A. J. (1979). Chemical geothermometry in geothermal systems. Chemical Geology, 25(3), 219-226. https://doi.org/10.1016/0009-2541(79)90143-8

Giggenbach, W. F. (1991). Chemical techniques in geothermal exploration. In Application of geochemistry in resources development (pp. 119-144). Exploration. New Zealand: Chemistry Division, DSIR, Private Bag.

Hutapea F. (2010). Eksplorasi Panas Bumi Dengan Metode Geofisika Dan Geokimia Pada Daerah Bonjol, Kabupaten Pasaman-Sumatra Barat. Institut Teknologi Bandung.

Kementrian ESDM. (2005). Blueprint Pengelolaan Energi Nasional 2005 - 2025.

Konstantinou, K. I., Perwita, C. A., Maryanto, S., Budianto, A., Hendrasto, M., \& Surono. (2013). Maximal 
Lyapunov exponent variations of volcanic tremor recorded during explosive and effusive activity at Mt Semeru volcano, Indonesia. Nonlinear Processes in Geophysics, 20(6), 1137-1145. https://doi.org/10.5194/npg-20-1137-2013

Maryanto, S., Dewi, C. N., Syahra, V., Rachmansyah, A., Foster, J. H., Nadhir, A., \& Santoso, D. R. (2017). Magnetotelluric-geochemistry investigations of blawan geothermal field, East Java, Indonesia. Geosciences (Switzerland), 7(2), 41. https://doi.org/10.3390/geosciences7020041

Nasional, B. S. (1998). SNI Klasifikasi Potensi Energi Panas Bumi di Indonesia. In Badan Standardisasi Nasional (Vol. 20, Issue 02, pp. 85-92).

Simmons, S. (Geothermal I. the U. of A. (1998). Geochemistry lecture notes 1998 (Vol. 18). University of Auckland.

Suciningtyas, I. K. L. N., Maryanto, S., \& Rachmansyah, A. (2013). Distribution of Hot Springs Blawan-Ijen Based on Geoelectrical Resistivity Data. Natural B, 2(2), 164-171. https://doi.org/10.21776/ub.natural-b.2013.002.02.11

Sukhyar, R., Gurusinga, C., Widodo, S., Munandar, A., Dahlan, H., \& Wahyuningsih, R. (2014). Potential and Development of Indonesia Geothermal Resources.

van Hinsberg, V., Berlo, K., van Bergen, M., \& Williams-Jones, A. (2010). Extreme alteration by hyperacidic brines at Kawah Ijen volcano, East Java, Indonesia: I. Textural and mineralogical imprint. Journal of Volcanology and Geothermal Research, 198(1-2), 253-263. https://doi.org/10.1016/j.jvolgeores.2010.09.002

Zaennudin, A., Wahyudin, D., Surmayadi, M., \& Kusdinar, E. (2012). Hazard assessment of Ijen volcanic eruption East Java. J. Environ. Geol. Hazard, 3, 109-132. 